\title{
Subroutine \\ for the Calculation of CODEN Check Characters
}

U.S. PARTMENT OF COMMERCE National Bureau of $e^{- \text {'andards }}$ 100

5953 .738 
The National Bureau of Standards ${ }^{1}$ was established by an act of Congress March 3, 1901. The Bureau's overall goal is to strengthen and advance the Nation's science and technology and facilitate their effective application for public benefit. To this end, the Bureau conducts research and provides: (1) a basis for the Nation's physical measurement system, (2) scientific and technological services for industry and government, (3) a technical basis for equity in trade, and (4) technical services to promote public safety. The Bureau consists of the Institute for Basic Standards, the Institute for Materials Research, the Institute for Applied Technology, the Center for Computer Sciences and Technology, and the Office for Information Programs.

THE INSTITUTE FOR BASIC STANDARDS provides the central basis within the United States of a complete and consistent system of physical measurement; coordinates that system with measurement systems of other nations; and furnishes essential services leading to accurate and uniform physical measurements throughout the Nation's scientific community, industry, and commerce. The Institute consists of a Center for Radiation Research, an Office of Measurement Services and the following divisions:

Applied Mathematics-Electricity-Heat-Mechanics-Optical Physics-Linac Radiation ${ }^{2}-$ Nuclear Radiation ${ }^{2}-$ Applied Radiation ${ }^{2}$ - Quantum Electronics ${ }^{3}$ Electromagnetics ${ }^{3}$ - Time and Frequency ${ }^{3}$ - Laboratory Astrophysics ${ }^{3}-$ Cryo- $^{2}$ genics ${ }^{3}$.

THE INSTITUTE FOR MATERIALS RESEARCH conducts materials research leading to improved methods of measurement, standards, and data on the properties of well-characterized materials needed by industry, commerce, educational institutions, and Government; provides advisory and research services to other Government agencies; and develops, produces, and distributes standard reference materials. The Institute consists of the Office of Standard Reference Materials and the following divisions:

Analytical Chemistry-Polymers-Metallurgy-Inorganic Materials-Reactor Radiation-Physical Chemistry.

THE INSTITUTE FOR APPLIED TECHNOLOGY provides technical services to promote the use of available technology and to facilitate technological innovation in industry and Government; cooperates with public and private organizations leading to the development of technological standards (including mandatory safety standards), codes and methods of test; and provides technical advice and services to Government agencies upon request. The Institute also monitors NBS engineering standards activities and provides liaison between NBS and national and international engineering standards bodies. The Institute consists of the following divisions and offices:

Engineering Standards Services-Weights and Measures-Invention and Innovation-Product Evaluation Technology-Building Research-Electronic Technology-Technical Analysis-Measurement Engineering-Office of Fire Programs.

THE CENTER FOR COMPUTER SCIENCES AND TECHNOLOGY conducts research and provides technical services designed to aid Government agencies in improving cost effectiveness in the conduct of their programs through the selection, acquisition, and effective utilization of automatic data processing equipment; and serves as the principal focus within the executive branch for the development of Federal standards for automatic data processing equipment, techniques, and computer languages. The Center consists of the following offices and divisions:

Information Processing Standards-Computer Information-Computer Services - Systems Development-Information Processing Technology.

THE OFFICE FOR INFORMATION PROGRAMS promotes optimum dissemination and accessibility of scientific information generated within NBS and other agencies of the Federal Government; promotes the development of the National Standard Reference Data System and a system of information analysis centers dealing with the broader aspects of the National Measurement System; provides appropriate services to ensure that the NBS staff has optimum accessibility to the scientific information of the world, and directs the public information activities of the Bureau. The Office consists of the following organizational units:

Office of Standard Reference Data-Office of Technical Information and Publications-Library-Office of International Relations.

\footnotetext{
1 Headquarters and Laboratories at Gaithersburg, Maryland, unless otherwise noted; mailing address Washington, D.C. 20234

2 Part of the Center for Radiation Research.

${ }^{3}$ Located at Boulder, Colorado 80302.
} 
David Garvin

Physical Chemistry Division

Institute for Materials Research

National Bureau of Standards

Washington, D.C. 20234

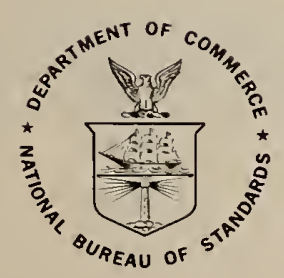

U.S. DEPARTMENT OF COMMERCE, Peter G. Peterson, Secretary NATIONAL BUREAU OF STANDARDS, Lawrence M. Kushner, Acting Director, 
National Bureau of Standards Technical Note 738

Nat. Bur. Stand. (U.S.), Tech. Note 738, 12 pages (Sept. 1972)

CODEN: NBTNAE

For sale by the Superintendent of Documents, U.S. Government Printing Office, Washington, D.C. 20402 (Order by SD Catalog No. C13.46:738). Price 25 cent s. 
Ca1culation of CODEN Check Characters

David Garvin

A FORTRAN subroutine is described that computes the check character for an ASTM CODEN for Journal Titles. This routine, written for input in Hollerith characters, is adaptable to other coding schemes. A listing of the routine is provided.

Keywords: Check character; CODEN; computer program; journal abbreviations.

\section{Introduction}

CODEN for journal titles are abbreviations, such as JCPSA, that provide a completely defined, short, frequently mnemonic identifier for a serial publication. This system is maintained by the American Society for Testing and Materials and is used both by information systems and some scientific journals.

When other identifiers are added to the CODEN a compact specific reference to an article can be obtained. E.g.

\section{Schofield IJCKBO-1972-4-255}

identifies an article by K. Schofield, Int. J. Chem. Kinetics, (1972) vo1. $4 \mathrm{pg}$. 255. In a similar manner the designation

$$
\text { IJCKBO 4(3) 255-336 (1972) }
$$

is used as a "bibliographic strip" to identify the page contents of issue no. 3 of volume 4 . This is useful in accession procedures in libraries.

The sixth character, " 0 " above, is a "check character" formed from the first five by a unique algorithm. It is used to spot transcription errors when the CODEN is keyboarded. 
In this note a FORTRAN subroutine is provided that calculates and verifies check characters for CODEN. The technical description starts in section 2 and the program listing is in section 4 . The application of the routine is discussed below. The algorithm given in the ASTM CODEN publication and used here is stated at the end of this section.

Application There are three types of potential uses for this subroutine.

(1) It may be used to generate check characters for CODEN for use in an information system. At present these characters are not given in the ASTM publication.

(2) It may be used to check the validity of CODEN keyboarded in constructing an information system. This is the most likely use in a sma11 system.

(3) It may serve as a benchmark routine against which the performance of more efficient routines can be tested. This is the most likely use in a large system.

The ASTM algorithm for check characters [1] is quoted below: "CHECK CHARACTERS

"The following information is included about check characters for those users of the CODEN system who may wish to use the character. Its purpose is to provide a letter or digit which, when properly calculated, will eliminate errors in CODEN notation in the keyboarding stage.

"The initial suggestion for the use of a machine-generated checkletter for controlling errors in CODEN came from A. D. Pratt at the School of Library Science, University of Indiana, Bloomington. F. E. Hajjar is responsible for reducing the idea to practice for Chemical Abstracts Service. The check-character becomes a sixth letter or digit whose value depends upon value and order of the five elements of the CODEN. Any error in a single letter or an inversion of letters, plus most other types of errors, will produce a check character that is inconsistent with the correct one and expose the error. Following is a brief description of the system as used at Chemical Abstracts Service. 
"1. CODEN may be entered as a 5- or 6-character field.

(a) If the CODEN is entered as a 5-character field, then a check-character is generated and added as a sixth character.

(b) If the CODEN is entered as a 6-character field, then a check-character is generated from the first five and matched with the sixth. If the check-characters match, the CODEN is verified as being valid. If the check-characters do not match, then the generated character replaces the original check-character and a switch is turned on to be interrogated by the operating program.

"2. The check-character is generated as follows:

(a) Each alpha-numeric character of the CODEN is replaced with an equivalent value. The equivalents are:

CODEN : $\quad A, B, \ldots \ldots . \quad \mathrm{Y}, \mathrm{Z}, 1,2, \ldots \ldots 9,0$

Equivalent: $\quad 1,2, \ldots \ldots 25,26,27,28, \ldots \ldots 35,36$

(b) The equation used to generate the check-character is:

$$
\frac{\left(11 \mathrm{xN}_{1}\right)+\left(7 \mathrm{xN}_{2}\right)+\left(5 \mathrm{xN}_{3}\right)+\left(3 \mathrm{xN}_{4}\right)+\left(1 \mathrm{xN}_{5}\right)}{34}=\mathrm{x}+\frac{\text { remainder }}{34}
$$

Where $\mathrm{N}_{1}$, $\mathrm{N}_{2}$, etc. are the equivalents of the CODEN characters in order of their appearance in the CODEN and $X$ is a whole number that is discarded.

(c) The remainder is converted to a check-character by the following set of equivalents:

$$
\begin{aligned}
& \text { remainder: } 1,2, \ldots .25,26,27,28,29, \ldots 33,34 \\
& \quad[34=0] \\
& \text { Check-character: A, B } \ldots . \mathrm{Y}, \mathrm{Z}, 2,3,4, \ldots 8,9 \\
& \quad[\text { or zero, }[\text { sic }])
\end{aligned}
$$

The numeric check-characters one (1) and zero (0) have been eliminated to avoid confusion with the alphabetic characters $I$ and 0 . 
(d) Sample calculation of a check character for the CODEN JACS -A:

$$
\begin{aligned}
& \mathrm{N}_{1}=\mathrm{J}=10 \\
& \mathrm{~N}_{2}=\mathrm{A}=1 \\
& \mathrm{~N}_{3}=\mathrm{C}=3 \\
& \mathrm{~N}_{4}=\mathrm{S}=19 \\
& \mathrm{~N}_{5}=\mathrm{A}=1
\end{aligned}
$$

Substituting these equivalents for the characters in the CODEN into the equation yields an " $\mathrm{X}$ " of 5 and a remainder of 20 . The checkcharacter equivalent of 20 is $T$. Thus the complete CODEN with checkcharacter is JACS-AT."<smiles>[3H]</smiles>

The rule as applied in this program calculates $X$ then uses the formula

$$
(\mathrm{X}-1) \operatorname{Mod} 34+1=\mathrm{C}
$$

where $\mathrm{C}$ is the check character. This rule is implied in paragraph $2 \mathrm{c}$ in the quotation, where a remainder of zero must be assigned to the check character nine (9).

\section{GENERAL DESCRIPTION OF PROGRAM}

Name: Subroutine CODCHK (LINE, MINE, IS, IL, IERR)

Language: Fortran IV with "implied do loop" DATA statements

Purpose: Calculation of (or verification of) the check character of a CODEN for Periodical Titles. Uses the algorithm stated in ASTM DS 23B, vo1. $1 \mathrm{pg}$. ix.. [1].

Forma1 Arguments: LINE: Integer array

MINE: Integer array, 6 words minimum IS, IL, IERR: Integers

Input Required: The CODEN is to be processed is suppled to the routine in the array LINE, one character per word. It is located in the zone LINE (IS) to LINE (IL) where IS and IL are the left and right limits, IS $<I L$. It is the only item in this zone. In this version the characters are assumed to be Hollerith, in A1 (left adjusted) format.

The first six non-blank characters are processed. Embedded blanks and minus signs are ignored. The sixth character may be missing. Examples of acceptable CODEN are

$$
\begin{gathered}
\text { JACSA, JACS-A, JACS A, JACSAT, } \\
\text { J A C S A T }
\end{gathered}
$$


Signals returned: Input errors are signalled by a non-zero value of IERR returned by the routine
IERR $=0$
Successful calculation
$=1$
Check character provided at input did not match the calculated one
$=2$
There were more than six characters in the input (first six used)
$=4$
There were fewer than five legal characters in the input (no calculation made)
$=8$
Illegal character in the input (ignored)

These signals are additive.

Text returned: The routine returns a six character CODEN in MINE, one character per word, Al format. The sixth character is the check character (except when IERR=4, in which case MINE (6) is left blank).

\section{REMARKS :}

Subroutine operation: The input characters are converted to integers using a table search of a dictionary, INDICT. The word INDICT (K) contains the character that corresponds to the integer $\mathrm{K}$ in the algorithm. A similar dictionary, JøDICT, is used to convert the integer value of the check character to the character itself. Both dictionaries in this version contain left adjusted Hollerith characters. Other character codes may be substituted. The two constants used in the program, blank and minus, are defined in data.

This table search procedure is much slower than a table look-up based on right adjusted integers. Any production program should use the latter technique. The search procedure is used here because ANSI FORTRAN does not provide for shifting Hollerith characters, this being the language feature needed if the procedure is to be changed.

Relation to other routines: This subroutine must be called into action by another program. The essential function of the calling program is to isolate the CODEN, that is, to set pointers (IS and IL) showing where in the array LINE the CODEN (and only it) is located. The calling program must also dispose of the result returned: print error messages, replace the old with the new, etc. The nature of this calling routine cannot be specified here since it must be constructed to match the file of material that is to be examined. (However, a sample is included in the program 1isting). 
4. PROGRAM LISTING:

Listings of two routines are attached. These are subroutine CODCHK, which does the work, and Main program CODEN, which is an example showing how CODCHK can be used with simple card input. An example of the output follows the listings.

[1] Blumentha1, J. G., Karaman, M. and Peters, A. "CODEN for Periodical Titles" ASTM Data Series DS 23B (American Society for Testing and Materia1s, Philadelphia, 1970), Volume 1 pgs ix-x. 
SUBROUTINE CODCHK(LINE,MINE, IS, IL, IERR)

DIMENSION LINE (I), MINE ( I)

C SIZES OF LINE AND MINE ARE SET IN CALLING PROGRAM

C MINIMUM IS 6 WORDS EACH

DIMENSION INDICT $(36)$, JODICT (34), LIN2(6)

C ROUTINE COMPUTES A CHECK CHARACTER FOR A CODEN

THESE FORMS

JACSA JACS-A JACS A JACSAT

(EMBEDDED BLANKS AND DASH IGNORED)

ROUTINE RECEIVES SIX CHAR (AI FORMAT) IN -LINE- AND RETURNS

SIX CHAR (AI FORMAT) IN MINE. THE SIXTH CHAR IN MINE IS THE

CHECK CHARACTER CALC PER PG IX-X OF ASTM DATA SER. DS 23 B

THE ARRAY LINE IS NOT CHANGED.

IF THE INCOMING CODEN HAD A CHECK CHAR., THAT IS COMPARED WITH THE CALC MADE HERE.

THE FORMAL ARGUMENT -IERR- IS RETURNED WITH THESE VALUES

AND MEANINGS

$I E R R=0 \quad O K$

IERR $=1$ CHECK CHAR DID NOT MATCH

IERR $=2$ CODEN HAD MORE THAN 6 CHARACTERS (FIRST 6 USED)

IERR $=4$ CODEN HAD LESS THAN 4 CHARACTERS (NO CALC. MADE)

IERR $=8$ ILLEGAL CHARACTER IN CODEN

CONSTANTS

DATA IBLNK,IMIN/ IH, IH-/

DICTIONARIES

C INPUT ABCDEFGHIJKLMNOPQRSTUVWXYZ1234567890

OUTPUT ABCDEFGHIJKLMNOPQRSTUVWXYZ23456789

INPUT CHAR DICTIONARY

(36)

$(34)$

DATA (INDICT(I), I =1,36) /

$11 \mathrm{HA}, 1 \mathrm{HB}, 1 \mathrm{HC}, 1 \mathrm{HD}, 1 \mathrm{HE}, 1 \mathrm{HF}, 1 \mathrm{HG}, 1 \mathrm{HH}, 1 \mathrm{HI}, 1 \mathrm{HJ}, 1 \mathrm{HK}, 1 \mathrm{HL}, 1 \mathrm{HM}, 1 \mathrm{HN}, 1 \mathrm{HO}, 1 \mathrm{HP}$,

$2 \mathrm{HQ}, 1 \mathrm{HR}, 1 \mathrm{HS}, 1 \mathrm{HT}, 1 \mathrm{HU}, 1 \mathrm{HV}, 1 \mathrm{HW}, 1 \mathrm{HX}, 1 \mathrm{HY}, 1 \mathrm{HZ}$,

$3 \mathrm{HH}, 1 \mathrm{H} 2,1 \mathrm{H} 3,1 \mathrm{H} 4,1 \mathrm{H} 5,1 \mathrm{H} 6,1 \mathrm{H} 7,1 \mathrm{H} 8,1 \mathrm{H} 9,1 \mathrm{HO} /$

OUTPUT DICTIONARY FOR CHECK CHARACTER

DATA $(J O D I C T(I), I=1,34) /$

$11 \mathrm{HA}, 1 \mathrm{HB}, 1 \mathrm{HC}, 1 \mathrm{HD}, 1 \mathrm{HE}, 1 \mathrm{HF}, 1 \mathrm{HG}, 1 \mathrm{HH}, 1 \mathrm{HI}, 1 \mathrm{HJ}, 1 \mathrm{HK}, 1 \mathrm{HL}, 1 \mathrm{HM}, 1 \mathrm{HN}, 1 \mathrm{HO}, 1 \mathrm{HP}$,

$21 \mathrm{HQ}, 1 \mathrm{HR}, 1 \mathrm{HS}, 1 \mathrm{HT}, 1 \mathrm{HU}, 1 \mathrm{HV}, 1 \mathrm{HW}, 1 \mathrm{HX}, 1 \mathrm{HY}, 1 \mathrm{HZ}$,

$3 \mathrm{HH}, 1 \mathrm{H} 3,1 \mathrm{H} 4,1 \mathrm{H} 5,1 \mathrm{H} 6,1 \mathrm{H} 7,1 \mathrm{H} 8,1 \mathrm{H} 9 /$

DO $10 \quad I=1,6$

$\operatorname{MINE}(I)=1 \mathrm{H}$

$10 \quad \operatorname{LIN2}(I)=0$

$I E R R=0$

$M O D E=0$

$K=0$

IF (IL-IS-4) $140,20,20$

C SEARCH INDICT FOR THE CHARACTERS

IGNORE BLANKS AND MINUS

CDK

CDK

CDK $2 A$

CDK 28

CDK 3

CDK 4

CDK 5

CDK 6

CDK 7

CDK 8

CDK 9

CDK 10

CDK 11

CDK 12

CDK 13

CDK 14

CDK 15

CDK 16

CDK 17

CDK 18

CDK 19

CDK 20

CDK 21

CDK 22

CDK 23

CDK 24

CDK 25

CDK 26

CDK 27

CDK 28

CDK 29

CDK 30

CDK 31

CDK 32

CDK 33

CDK 34

CDK 35

CDK 36

CDK 37

CDK 38

CDK 39

CDK 40

CDK 41

CDK 42

CDK 43

CDK 44

CDK 45

CDK 46

IF (LINE(I)-IBLNK) $30,80,30$

30 IF (LINE(I)-IMIN) $40,80,40$

40 DO $50 \mathrm{~J}=1,36$

IF (LINE(I)-INDICT (J)) $50,60,50$

50 CONTINUE

C ILLEGAL CHARACTER

IF (IERR.LT.8) IERR=IERR +8

GO TO 80

$C$ CONVERT VALUE TO AN INTEGER

$60 \quad K=K+1$

IF (K.LE.6) GO TO 70

C MORE THAN 6 CHAR IN FIELD

IF (MOD (IERR, 4) $L E .1)$ IERR =IERR +2

GO TO 90

70

$L I N 2(K)=J$

CDK 47

CDK 48

CDK 49

CDK 50

CDK 51

$\operatorname{COK} 52$

CDK 53

CDK 54

CDK 55

CDK 56

CDK 57

CDK 58

CDK 59 


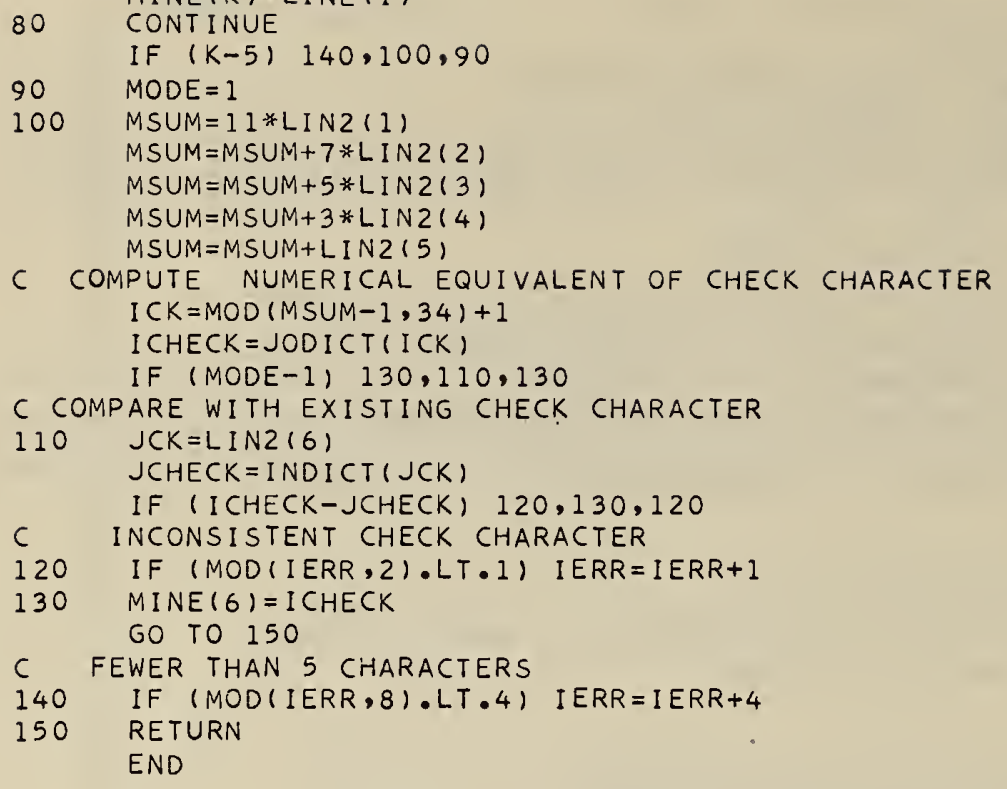

C SAMPLE MAIN PROGRAM FOR CODEN INPUT FROM CARDS

CDN DIMENSION LINE(80),MINE(80)

C CARD READER AND PRINTER UNITS

$K R=5$

$K P=6$

C ZONE ON THE INPUT WHERE CODEN IS LOCATED

I $1=1$

I $2=10$

PRINT 10

10 FORMAT ('I OUTPUT INPUT FOR CODEN (HECK PROGRAMI)

C READ THE INPUT. THIS IS UNIVAC FORTRAN $V$

20 READ (KR, 40, END $=70)$ (LINE(I), I =1,80)

CALL COOCHK (LINE,MINE, I I, I 2, IERR)

IF (IERR・EQ.0) GO TO 30

WRITE (KP,50) IERR

30 WRITE (KP,60) (MINE(I), I = I,6), (LINE(I), I =II, I 2) GO TO 20

40 FORMAT (80A1)

50 FORMAT $(1 * * * * *$ ERROR TYPE'I3,1 ON NEXT CARD!)

$C$ FORMAT FOR ARRAY LINE SHOULD ALLOW FOR I $2-I 1+1$ CHARACTERS

60 FORMAT (1H 6A1, 6X,30A1)

70 STOP

END

$C D N$

CDN 
OUTPUT INPUT FOR CODEN CHECK PROGRAM

***** ERROR TYPE 4 ON NEXT CARD

$A B C D \quad A B C D$

**** ERROR TYPE 3 ON NEXT CARD

ABCDEW ABCDEFG

ANYAA9 ANYAA

APOPAI APOPA

***** ERROR TYPE 1 ON NEXT CARD

CHREAY CHREAB

***** ERROR TYPE 8 ON NEXT CARD

GCAXZ6 *GCAXZ

***** ERROR TYPE 8 ON NEXT CARD

GCAXZ6 GC*AXZ

***** ERROR TYPE 12 ON NEXT CARD

GCAZ GC*A*Z

IJCKBO IJCKB

JACSAT JACSA

JACSAT JACS-A

JACSAT J A C SAT

**** ERROR TYPE 1 ON NEXT CARD

JASCAR JASCAT

JATPA3 JATPA

JGREA2 JGREA

NBCIAG NBCIA

NBCIAG NBCIA-G 
FORM NBS-114A (1.71)

\begin{tabular}{|c|c|c|c|}
\hline $\begin{array}{l}\text { U.S. DEPT. OF COMM. } \\
\text { BIBLIOGRAPHIC DATA } \\
\text { SHEET }\end{array}$ & $\begin{array}{l}\text { 1. PUBLICATION OR REPORT NO. } \\
\text { NBS TN }-738\end{array}$ & $\begin{array}{l}\text { 2. Gov't Accession } \\
\text { No. }\end{array}$ & 3. Recipient's Accession No. \\
\hline \multirow{2}{*}{\multicolumn{3}{|c|}{ Subroutine for the Calculation of CODEN check Characters }} & $\begin{array}{l}\text { 5. Publication Date } \\
\text { September } 1972\end{array}$ \\
\hline & & & 6. Performing Organization Code \\
\hline \multicolumn{3}{|l|}{ 7. AUTHOR(S) } & 8. Performing Organization \\
\hline \multicolumn{3}{|c|}{ 9. PERF ORMING ORGANIZATION NAME AND ADDRESS } & 10. Project/Task/Work Unit No. \\
\hline \multicolumn{3}{|c|}{$\begin{array}{l}\text { NATIONAL BUREAU OF STANDARDS } \\
\text { DEPARTMENT OF COMMERCE } \\
\text { WASHINGTON, D.C. } 20234\end{array}$} & 11. Contract/Grant No. \\
\hline \multirow{2}{*}{\multicolumn{3}{|c|}{ 12. Sponsoring Organization Name and Address }} & $\begin{array}{l}\text { 13. Type of Report \& Period } \\
\text { Covered } \\
\text { Final }\end{array}$ \\
\hline & & & 14. Sponsoring Agency Code \\
\hline
\end{tabular}

16. ABSTRACT ( 200 -word or less factual summary of most significant information. If document includes a significant bibliography or literature survey, mention it here.)

A FORTRAN subroutine is described that computes the check character for an ASTM CODEN for Journal Titles. This routine, written for input in Hollerith characters, is adaptable to other coding schemes. A listing of the routine is provided.

17. KEY WORDS (Alphabetical order, separated by semicolons)

Check characters; CODEN; computer program; journal abbreviations.

\begin{tabular}{|c|c|c|}
\hline $\begin{array}{l}\text { 18. AVAILABILITY ST ATEMENT } \\
\mathrm{X} \text { UNL IMITED. }\end{array}$ & $\begin{array}{l}\text { 19. SECURITY CLASS } \\
\text { (THIS REPORT) } \\
\text { UNCL ASSIFIED }\end{array}$ & $\begin{array}{l}\text { 21. NO. OF PAGES } \\
12\end{array}$ \\
\hline $\begin{array}{l}\square \text { FOR OFFICIAL DISTRIBUTION. DO NOT RELEASE } \\
\text { TO NTIS. }\end{array}$ & $\begin{array}{l}\text { 20. SECUR ITY CLASS } \\
\text { (THIS PAGE) } \\
\text { UNCL ASSIFIED }\end{array}$ & $\begin{array}{l}\text { 22. Price } \\
25 \text { cents }\end{array}$ \\
\hline
\end{tabular}


PERIODICALS

JOURNAL OF RESEARCH reports National Bureau of Standards research and development in physics, mathematics, and chemistry. Comprehensive scientific papers give complete details of the work, including laboratory data, experimental procedures, and theoretical and mathematical analyses. Illustrated with photographs, drawings, and charts. Includes listings of other NBS papers as issued.

Published in two sections, available separately:

\section{- Physics and Chemistry}

Papers of interest primarily to scientists working in these fields. This section covers a broad range of physical and chemical research, with major emphasis on standards of physical measurement, fundamental constants, and properties of matter. Issued six times a year. Annual subscription: Domestic, $\$ 9.50 ; \$ 2.25$ additional for foreign mailing.

\section{- Mathematical Sciences}

Studies and compilations designed mainly for the mathematician and theoretical physicist. Topics in mathematical statistics, theory of experiment design, numerical analysis, theoretical physics and chemistry, logical design and programming of computers and computer systems. Short numerical tables. Issued quarterly. Annual subscription: Domestic, $\$ 5.00$; $\$ 1.25$ additional for foreign mailing.

\section{TECHNICAL NEWS BULLETIN}

The best single source of information concerning the Bureau's measurement, research, developmental, cooperative, and publication activities, this monthly publication is designed for the industry-oriented individual whose daily work involves intimate contact with science and technology-for engineers, chemists, physicists, research managers, product-development managers, and company executives. Includes listing of all NBS papers as issued. Annual subscription: Domestic, $\$ 3.00 ; \$ 1.00$ additional for foreign mailing.

\section{Bibliographic Subscription Services}

The following current-awareness and literaturesurvey bibliographies are issued periodically by the Bureau: Cryogenic Data Center Current Awareness Service (weekly), Liquefied Natural Gas (quarterly), Superconducting Devices and Materials (quarterly), and Electromagnetic Metrology Current Awareness Service (monthly). Available only from NBS Boulder Laboratories. Ordering and cost information may be obtained from the Program Information Office, National Bureau of Standards, Boulder, Colorado 80302 .

\section{NONPERIODICALS}

Applied Mathematics Series. Mathematical tables, manuals, and studies.

Building Science Series. Research results, test methods, and performance criteria of building materials, components, systems, and structures.

Handbooks. Recommended codes of engineering and industrial practice (including safety codes) developed in cooperation with interested industries, professional organizations, and regulatory bodies.

Special Publications. Proceedings of NBS conferences, bibliographies, annual reports, wall charts, pamphlets, etc.

Monographs. Major contributions to the technical literature on various subjects related to the Bureau's scientific and technical activities.

National Standard Reference Data Series. NSRDS provides quantitative data on the physical and chemical properties of materials, compiled from the world's literature and critically evaluated.

Product Standards. Provide requirements for sizes, types, quality, and methods for testing various industrial products. These standards are developed cooperatively with interested Government and industry groups and provide the basis for common understanding of product characteristics for both buyers and sellers. Their use is voluntary.

Technical Notes. This series consists of communications and reports (covering both other-agency and NBS-sponsored work) of limited or transitory interest.

Federal Information Processing Standards Publications. This series is the official publication within the Federal Government for information on standards adopted and promulgated under the Public Law 89-306, and Bureau of the Budget Circular A-86 entitled, Standardization of Data Elements and Codes in Data Systems.

Consumer Information Series. Practical information, based on NBS research and experience, covering areas of interest to the consumer. Easily understandable language and illustrations provide useful background knowledge for shopping in today's technological marketplace.

\section{CATALOGS OF NBS PUBLICATIOHS}

NBS Special Publication 305. Publications of the NBS. 1966-1967. When ordering, include Catalog No. C13.10:305. Price \$2.00: 50 cents additional for foreign mailing.

NBS Special Publication 305, Supplement 1, Publications of the NBS, 1968-1969. When ordering, include Catalog No. C13.10:305/Suppl. 1. Price \$4.50: $\$ 1.25$ additional for foreign mailing.

NBS Special Publication 305, Supplement 2, Publications of the NBS, 1970. When ordering, include Catalog No. C13.10:305/Suppl. 2. Price $\$ 3.25 ; 85$ cents additional for foreign mailing.

Order NBS publications (except Bibliographic Subscription Services) from: Superintendent of Documents, Government Printing Office, Washington, D.C. 20402. 
U.S. DEPARTMENT OF COMMERCE

National Bureau of Standards

Washington, D.C. 20234

PDSTAGE AND FEES PAID

DFFICIAL BUSINESS

U.S. DEPARTMENT OF CDMMERCE 215

Penalty for Private Use, $\$ 300$ 